\title{
PROCEEDINGS OF \\ The role of management accounting in the construction of the new generation leadership in family firms: An Actor- Reality perspective
}

\author{
Antonio Leotta \\ Associate Professor in Management Accounting \\ Department of Economics and Business, University of Catania, \\ Corso Italia 55, 95129 Catania, Italy; antonio.leotta@unict.it \\ Carmela Rizza \\ Assistant Professor in Management Accounting \\ Department of Economics and Business, University of Catania, \\ Corso Italia 55, 95129 Catania, Italy; c.rizza@unict.it \\ Daniela Ruggeri \\ Research Fellow in Management Accounting \\ Department of Economics and Business, University of Catania, \\ Corso Italia 55, 95129 Catania, Italy; d.ruggeri@unict.it
}

\begin{abstract}
Succession in family firms may determine the survival or the failure of the business itself. Management accounting literature has added little to this issue, mainly focusing on the process of succession and change (Songini et. al, 2013; Giovannoni et al., 2011). The present study deals with new management accounting (MA) practices that the junior generation may introduce during the process of succession. The aim of the study is to show that the introduction of new MA practices can contribute to construct the leadership profile of the junior generation. Drawing on the perspective of Actor-Reality Construction, we conducted a case study at a small-sized, family firm producing solar shading systems. We examined how the process of succession derives from the integration of four dimensions of reality: facts, possibilities, values and communication. Such an integration is facilitated by the introduction of a new accounting information system and cost report. The case evidence highlights that the construction of the new generation leadership may emerge as unintended consequence of the introduction of new MA practices. From the emergent perspective of Actor-Reality Construction, the paper investigates the role of new management accounting practices in the actor-world relation constructing the new generation leadership.
\end{abstract}

Keywords: Succession; actor-reality construction; management accounting practices. 


\section{Introduction}

In the family business literature, the process of succession is considered as one of the most critical issues (Cater and Justis, 2009; Salvato and Corbetta, 2013). As such, it may be prepared and planned (Giovannoni et al., 2011) in the aim of addressing its radical effects so as to benefit the long-term performance of the family firm.

Family business studies construe succession as "the actions, events, and organizational mechanisms by which leadership at the top of the firm, and often ownership, are transferred” Le Breton-Miller et al., (2004, p. 3005). Hence, as noticed by Salvato and Corbetta (2013), "the development of successors' leadership has been primarily interpreted as resulting more from incumbents letting go and transferring their power and roles, than from successors developing their legitimacy within the family and the firm and constructing their own leadership profile” (Salvato and Corbetta, 2013, p. 235). Focused on the process of succession preparation, this paper is in line with Salvato and Corbetta in viewing succession as a process of constructing the successors' leadership.

Management accounting topics has been largely unexplored in family business settings, and particularly in relation to the specific issue of succession (Songini et al., 2013). Giovannoni and Maraghini (2013) examined the challenges of Performance Measurement System (PMS) development process within a family firm, while, focusing on the process of succession, Giovannoni et al. (2011) dealt with the role of management accounting practices in transmitting knowledge and values across generations. Bracci and Maran (2012) examined the role of management accounting systems in family firms during a process of succession, highlighting how such systems contribute to constructing trust in the successors.

The present study deals with new management accounting (MA) practices that the junior generation may introduce during the process of succession. The aim of the study is to show that the introduction of new MA practices can contribute to construct the leadership profile of the junior generation.

How can management accounting contribute to build the trustworthiness of the successor? How does management accounting help the successor to communicate his/her vision with the rest of the family organisation establishment? To the best of our knowledge, no previous study has dealt with these questions. In addressing such questions, we see management accounting as the language that, under the values shared within the family organisation, makes a link between the present and the future, namely, between facts and possibilities. So, the paper draws on the perspective of Actor-Reality Construction in order to propose a theoretical interpretation of the phenomenon, viewed as a construction of facts, possibilities, values and communication. This interpretation informs a case study at a smallsized, family firm producing solar shading systems. We examined how the process of succession derives from the integration of four dimensions of reality, mentioned above. Such an integration is facilitated by the introduction of a new accounting information system and cost report.

The paper contribution is threefold. First, from the emergent perspective of Actor-Reality Construction, the paper investigates the role of new management accounting practices in the actor-world relation constructing the new generation leadership. Second, the case evidence highlights that the construction of the new generation leadership can be partially unintentional as it may emerge as unintended consequence of the introduction of new MA practices. Third, the field evidence highlights that the construction of the new generation leadership is a process that integrates the four dimensions of reality, but it starts from a fact, instead from values, namely the succession in the firm.

The rest of the paper is structured as follows. Section 3 discusses successions in family firms drawing on the extant literature, with a focus on succession preparation. Section 4 deals with the construction of successor's leadership as a problem to be solved while preparing succession. Section 5 discusses literature on new management accounting practices and innovations in family firms and concentrates on previous studies on management accounting practices in succession processes. The aim of the section is to interpret the role of such practices from the lens of Actor-Reality perspective. While research methodology and method are exposed in section 6, section 7 illustrates the case firm's profile and the field evidence. Section 8 discusses the empirical findings and concludes the paper.

\section{Theoretical background}

\subsection{The succession process in family firms}

In the family business literature, the succession process has been defined as the set of "actions, events, and organisational mechanisms by which leadership at the top of the firm, and often ownership, are transferred” (Le BretonMiller et al., 2004). This process may occur in case of the incumbent's death or unexpected retirement, or it can be 
anticipated (Giovannoni et al., 2011). In the latter case, the incumbent's retirement is preceded by a period of preparation during which succession must be anticipated long in advance, and managed as a planned process (Dyer, 1986, Ward, 1987; Lansberg, 1988, 1999; Malone, 1989; Handler, 1990; Sharma et al., 2001; Dyck et al., 2002; Cabrera-Suárez et al., 2001; Le Breton-Miller et al., 2004). Succession planning means "making the preparations necessary to ensure the harmony of the family and the continuity of the enterprise through the next generation. These preparations must be thought of in terms of the future needs of both the business and the family” (Lansberg, 1988, pag. 25).

Several contributions on family firm's succession have mainly highlighted business factors as elements which affect family business succession, such as previous experience with the succession and the influence of a board directors (Fox et al., 1996; Sharma et al., 2001; Dyck et al., 2002; Le Breton-Miller et al. 2004).

The succession planning refers to the deliberate and formal process that facilitates the transfer of firm leadership from one family member to another (Sharma et al., 1997). Dyck et al. (2002) argued that the succession process includes both selection and training of the successor, ensuring the successor has the appropriate skills and experience to lead the organisation in its next phase (Dyck, et al. 2002). They also identified the modality how the succession will be achieved, defining the post-succession role of the retiring incumbent and developing a strategic plan for the company after succession.

The process of preparing junior generation goes through to acquire knowledge, develop capabilities, and achieve credibility and legitimacy. Cabrera-Suárez et al. (2001) emphasised that such processes are affected by the extent to which knowledge and capabilities are transferred across generations. Mazzola et al. (2008) showed that involving nextgeneration members in the strategic planning process provides them with tacit business knowledge and skills which support the succession process.

\subsection{The leadership construction in family firms}

Some contributions on family business literature have envisioned succession as transfer of leadership role from incumbent leader to a next-generation member (Cater and Justis, 2009).

As argued by Le Breton-Miller et al. (2004), ensuring competent family leadership across generations represents one of the most critical challenges facing family firms, which often do not survive into the third generation mainly because of poor preparation during the succession processes (Birley, 1986; Miller et al., 2003).

On this issue, there has been limited attention toward developing a systematic understanding of how successors' leadership is best nurtured and developed. Dyer (1986) provides insights into the types of leadership prominent in family businesses categorising four cultures that respectively portray different forms of management behaviour. The literature about family firm’s succession has focused primarily on developing successors' business knowledge and technical skills, typically through the acquisition of professional experience outside the family firm, or through on-thejob training (Venter et al., 2005; Sardeshmukh and Corbett, 2011; Stewart and Hitt, 2012). In addition, the development of successors' leadership has been interpreted as resulting more from incumbents letting go and transferring their power and roles, than from successors developing their legitimacy within the family and the firm and constructing their own leadership profile (Cadieux, 2007; De Massis et al., 2008; Chlosta et al., 2012; Salvato and Corbetta, 2013).

Within current family business literature, the succession process is often interpreted as the set of actions, events, and organisational mechanisms by which leadership, ownership, and knowledge are transferred. Therefore, development of the successor's leadership is modelled as a series of steps or milestones (Cater and Justis, 2009) through which formal power, ownership, and business knowledge are transferred from the incumbent to the next-generation leader. These steps are premised on a strong commitment by the successor to become a successful leader (Barach and Gantisky, 1995) hence assuming that leadership is something that is nearly automatically and uneventfully developed by the successor, by virtue of his or her position within the controlling family.

The succession preparation involves a large number of actors, such as the incumbent leader and the successor but also all family and nonfamily members, which contribute to the construction of junior generation leadership. Some critical issues come to light in the succession preparation process. Why are some successors not seen as leaders even after the formal transfer of ownership and decision power? Why are some former incumbents still seen as leaders despite having transferred their leader positions (Le Breton-Miller et al., 2004; De Massis et al., 2008; Cater and Justis, 2009)? 
In addressing the above questions an important aspect consists in understanding how leadership is developed both in the mind of the next generation leader, and in those of his or her followers, including the former leaders of the senior generation, and how the leadership is accepted by all the actors involved.

Some contribution on organisational science have investigated the leadership as co-constructed, a product of socio-historical and collective meaning making, and negotiated on an ongoing basis through a complex interplay among leadership actors, be they designated or emergent leaders, managers, and/or followers (Meindl, 1995; Grint, 2005; Collinson, 2006; Vine et al., 2008). Social constructionist approaches (Fairhurst and Grant, 2010) commonly exhibit two interrelated characteristics. First, they eschew a leader-centric approach in which the leader's personality, style, and/or behaviour are the primary determining influences on follower's thoughts and actions (Smircich and Morgan, 1982; Fairhurst, 2001). Second, emphasis is given to leadership as a co-constructed reality, in particular, the processes and outcomes of interaction among social actors. Communicative practices-talk, discourse, and other symbolic media-occasioned by the context are integral to the processes by which the social construction of leadership is brought about (Fairhurst, 2009; De Rue and Ashford, 2010).

There is still little research on the leadership processes or collective acts of leadership as processes in which emergent coordination and change are constructed (Uhl-Bien, 2006). For this reason, there is a need for more research in family firm's succession on how these processes are made sense of through social interactions, not only in the followers' minds. Furthermore, research is needed on how the leadership processes contribute to the construction or reconstruction of the leadership ideal and the organisational context of family-owned businesses, developing the ability to ensure competent family leadership across generations (Le Breton-Miller et al., 2004; Lansberg, 2007). Recently, Salvato and Corbetta (2013) argued that succession is a social process through which leadership is gradually constructed through the contribution of a broad group of actors (all family and nonfamily members) within and outside the organisation. Specifically, advisors may play a role in affecting the relational processes through which successors come to see themselves, and be seen by others as family business leaders. By assuming a transitional leadership role shared with incumbent senior leaders and the selected successor, advisor facilitates the process through which juniors' leadership gradually becomes clear and accepted by all actors involved. In particular, a deeper understanding of how leadership is constructed in next-generation members would help explain and predict whether individuals will actually relate with each other as leaders, followers, and former leaders turned into followers. For instance, the development of a strong leadership by the successor implies that there is greater acceptance of the right of the person designated as nextgeneration leader to exert influence over the other family business members, including former senior-generation incumbents. On the opposite, when a strong leadership is not constructed, we expect increased conflicts and tensions in the relationship between the new leader and followers from both the previous and the next generation.

\subsection{Management accounting practices in the process of succession}

Little has been added by management accounting literature to the topic of family business, (Songini et. al., 2013). Regarding the process of succession, as argued by Salvato and Moores (2010), scholars in the field of family business have yet to dedicate adequate attention to the role of management accounting during such a process.

The family business literature has been enriched by recent contributions that analyse the role of new management accounting practices in such firms. Giovannoni and Maraghini (2013) examined the integration of PMS as a process of accounting change consisting in restructuring the current PMS by the implementation of an integrated report, which provided a comprehensive picture of the family firm's performance. This process of change involved all organisational actors in designing the performance indicators, setting target for each measures and assessing performance. In this context, the integration was achieved through the coordinating role of the founder, who directly monitored the progress made in the various areas and intervened to resolve any problems. The direct intervention of the founder acted as an additional mechanism complementing the integrating role of PMS.

Focusing on the process of succession, Giovannoni et al., (2011) explored management accounting changes during succession preparation. They highlighted that management accounting practices reinforced the influence of the founder, transferring his knowledge of the business across generations and to the family and non-family professional managers (Kelly et al., 2000). Management accounting practices facilitated internal communication and interaction, as well as the diffusion of a common vision of the business.

Bracci and Maran (2012), drawing on the institutional framework of management accounting change, investigated the role of management accounting innovations in building or dismantle trust and creating new organisational routines in family successions. More specifically, the succession process was viewed as a radical change whereby management accounting can be employed in order to rebuild conditions of trust and legitimacy among the successors, and between the successor and the rest of the organisation establishment (Busco et al., 2006). 
In these studies, management accounting practices and innovations have been examined as playing an integrating role in the family firm succession processes, but, to the best of our knowledge, no previous study has investigated the role of management accounting practices in the construction of successors' leadership profile. How can management accounting contribute to build the trustworthiness of the successor? How does management accounting help the successor to communicate his/her vision with the rest of the family organisation establishment? In addressing these questions, we see management accounting as organisational practices that help people to share a set of values which lead them during the formulation of the firm's strategy, namely during the selection of the business facts to consider relevant for the future possibilities of the business. In this view, management accounting provides organisational actors with a language that, under the values shared within the family organisation; makes a link between the present and the future, namely, between facts and possibilities.

Following this view, we draw on the emergent perspective of Actor-Reality Construction (ARC), which sees reality as a construction of four ontological dimensions: facts, possibilities, i.e. logic, values and communication (Nørreklit et al., 2006; Nørreklit et al., 2007; Nørreklit et al., 2010). The authors who proposed this perspective justified the inclusion of all the four dimensions as follows:

"Facts are necessary as a basis of action. Facts alone are insufficient. If there are no possibilities there can be no action.” (Nørreklit et al., 2010, p. 738)

And they continue:
"The possibilities must be grounded in the facts. Otherwise they are fictional. Further, possibilities create room for choice, but they only function if there is a reason to choose and prefer one possibility to the other i.e. if the actor has values and the values lie within the range of one's possibilities. Finally, the integration of facts, possibilities and value must be expressed in communication in order to enable action in a social setting." (ibidem, p. 738)

Nørreklit et al. (2010) apply this conceptual framework to accounting practices. The latter are viewed as a social reality constructed through the integration of all the four ontological dimensions mentioned above. The process of this integration is explained by the authors by describing how the four ontological dimensions relate to each other in the construction of the accounting practice. They argue that values are identified by accounting profession for the development of the principles, rules and procedures that constitute their practice. Given a set of adopted values, observation allows accountants to establish the facts which define their practice. Accounting possibilities are identified through the application of accounting reasoning and logic to the facts. Alternative possibilities are selected through the guidance of values. Such selected possibilities are then translated into information which is communicated to the users by the accounting methods developed for information reporting. So, the authors summarise:

"The pursuit of the profession's values through the activities of observation of various types of facts and the development of logic to derive the accounting possibilities from the facts and the subsequent communication of the resultant information comprises the integrated explanation of the accounting world." (Nørreklit et al., 2010, p. 747).

In line with the purpose of the present study, the conceptual framework described above is applied to the context of family firms. In this context, the family organisation share a set of values that lead the organisation members to select the facts considered relevant for the business and to design the possibilities for future actions, selected on the basis of the family values. The selected facts are then communicated by proper accounting reports.

This interpretation assumes the family values as stable and shared by all the organisation members, but this may not be the case during a process of succession preparation. In the process of succession preparation, indeed, the new generation can be the bringer of a new set of values, which may differ from the vision of the founder. These new values may derive from the new capabilities and skills developed by the successor and are relevant for the acceptance of the successor's leadership by the family and nonfamily members, including the founder. Furthermore, succession appears as a future fact that cannot be avoided. It is the awareness of this future fact that forces the family to confront its consolidated values with the new generation's ones. Thus, in its application to the process of successor's leadership construction, we interpret the Nørreklit et al.’s (2010) framework, by inverting its sequence and recognising facts, rather than values, the starting point of the integration process described by the authors. The construction of the successor's leadership profile can be successful when the successor's values and vision has proven effective in the selection of business facts and possibilities; but this needs to be communicated to the rest of the family organisation establishment. In line with the integrating role recognised to management accounting by the studies mentioned above, we see management accounting as organisational practices that can facilitate communications between the successor and the 
rest of the family organisation establishment. In doing so, management accounting can be seen as a communication practice that supports the construction of the successor's leadership by integrating facts and possibilities in line with the new values of the successor. The theoretical arguments discussed above inform a field study on succession preparation in a family firm, when the successor has played an active role in the introduction of a new accounting information system and cost report.

\section{Research methodology and methods}

In order to improve our understandings of the role played by management accounting in the process of succession preparation and, particularly, in the construction of successors' leadership profile, we use results of a case-study previously conducted at CTA. It is a small-sized, family firm producing solar shading systems, located in the south of Italy. We interpret the field evidence it in the light of a pragmatic constructivism approach.

According to the theoretical framework, reality is made by four integrated dimensions (facts, logic, communication and values) and the investigation of these dimensions and the associated beliefs allows to discover how organisational actors construct reality and performance concepts (Nørreklit et al., 2006; Nørreklit et al., 2010; Jakobsen et al., 2011; Seal, 2012; Mitchell et al., 2013).

The choice of this family firm was due to the characteristics of the succession process, which is happening inside and not outside the family and is involving family and nonfamily managers to different extents, in the entrance of a junior generation member at management level, preparing her to manage the family business.

The case research followed a narrative approach, intended to grasp subjects' stories and perceptions about the construction of the leadership during the succession preparation under study (Boje, 2001; Czarniawska, 1997; Scapens, 2004; Walsham, 2006). In our construction of these perceptions, we tried to direct the attention of the people in the field to the aspects they perceived as relevant in terms of both causes and consequences of the examined process of succession preparation and leadership construction. We also formed our own perception drawing on family firm's archival data, considering performance reports, client orders, stock accounts and other internal documents being relevant for the role played by management accounting innovations in the process of succession preparation.

Data were gathered over the period from 2010 to February 2015. Our retrospective approach limited data sources to archive and field data coming from interviews with the founder, the successor, the accountant, managers and employees. More specifically, we collected archive data from internal documents, such as sales reports, cost and performance reports, client orders, stock accounting reports, and from the firm's web site. Field data came from semistructured interviews conducted during the year 2015 with the founder, the successor and various subjects, who were selected from the managers and employees working at the family firm, namely the founder, the founder's daughter, the accountant, the customer manager and the production manager.

Following Yin (2003) and Auerbach and Silverstein (2003) interviews data have been categorised and coded in order to explain how actors involved in the process of leadership construction perceived the succession preparation, and to identify commonalities among them. Further interviews aimed at gathering individual stories and perceptions of the appropriateness of the new information system and cost report in supporting the sharing of key aspects and beliefs, which have been used to identify the reality of actors.

The interviews, which lasted an hour and twenty minutes on average, focused on: a) the perceived problems before the new information system and cost report had been introduced; b) the extent to which the new information system and cost report were perceived to be put into practice; c) the perceived advantages and main limits of the new management accounting tools; d) the extent to which the successor's ability to manage the new management accounting tools was acknowledged by all the other people. The interviews were not type-recorded because of the confidential nature of the issues discussed (Kajüter and Kulmala, 2005), and were conducted in an informal style; all were written down in a draft-report and shared with the interviewees.

The limit of relying on retrospective approach consists in asking interviewees to describe, explain and reflect on events they had experienced (Nor-Aziah and Scapens, 2007) as respondents misreport their past choices in order to appear more consistent with their current choice (Shachar and Eckstein, 2007). We do not see such a bias as a limit to the validity of this study, because we contain it through data triangulation. 


\title{
4 The family firm profile and the integrating role of new management accounting practices in the succession preparation
}

CTA is a family firm located in the south of Italy, which manufactures and installs tents and sunscreen. It was founded in 1983 and its objective is to maintain the market competitiveness offering a high product and service quality. To do so, it adopts advanced technological instruments, used by specialised work teams, which allow satisfying specific customers' requests.

The organisational complexity of CTA has recently increased, and the founder has perceived the need to delegate more and to prepare the organisation's members to the succession. At the time of the research, the CTA was totally owned by founder's family. Of the two daughters of the founder, the second was too younger to assume any role in the business. So, the oldest daughter was designated as the possible future successor and was introduced in the organisational profile of CTA. Cooperating with the founder, the junior generation aimed to spread managerial values into the organisation, introducing new management accounting practices, namely a new information system and cost report.

\subsection{Preparing succession. The awareness of an unavoidable fact}

The daughter of the founder, Lucia, started working in the family firm in 2010, even if at the beginning she was not completely devoted to the business until to her university career was completed. She began working during the summer seasons, following her father's suggestion to take part in the business. In doing so, she was involved in the development of various firm's projects, participating in the major trade shows and exhibitions CTA took part in. Successively, Lucia decided to learn more about her family firm in order to understand the dynamics among family members and employees and to take part in the firm's decision making. In this way, Lucia tried to follow her father's footsteps but this choice required a deeper knowledge of the administrative and production processes. Taking her undergraduate degree in Business Administration, Lucia devoted her thesis on the design of a cost report that was able to represent the profitability of the main CTA business areas. She explained her motivation arguing:

\begin{abstract}
"I needed to contribute to my family business applying what I had learnt from the management accounting course I attended. That was why I wanted to give my dad more information about the costs and revenues of the various business areas. The development of a cost report could bring me to the core of the production process and to all the business processes. This was a necessary condition in order to take part in the firm's decisions making”.
\end{abstract}

Lucia started constantly working at CTA in 2010. During the same year, a reorganisation of the office space was put in place. Previously, managers and employees had assigned their own rooms and communicated going from one room to another; and very often, the information shared between two managers remained blinded between them. In order to facilitate communication among people reducing the loss of time in sharing the information, the founder decided to create an open working space. In this context, Lucia had more chances to know how the firm's operations were running and how managers and employees were facing the problems and solving them. Referring to a specific situation where Customers Manager required information about the state of the client production order, Lucia argued:

"When the Customers Manager asked the Production Manager some pieces of information about one client order, the Production Manager, grumbling, answered that he needed more time because he had had to physically search for the client folder... So, they spent a lot of time in obtaining such information; meanwhile the customer was complaining".

\subsection{Selecting the values. The contribution of the successor as the bringer of a managerial view}

In order to deal with the above-mentioned information problems, Lucia proposed to introduce an integrated information system in order to assemble all the data on customers/suppliers, and to efficiently manage payments, avoiding the waste of time in the search of all clients' and suppliers' folders or in the check of the amount of materials in the warehouse. A problem such that was viewed by Lucia as:

"the problem of running the business in an old fashion, where information was still hidden in the memories of employees or encoded in some folder that was difficult to find. This was not a managerial style, where information was shared everywhere, regardless of the people involved in its management!" 
Some critical points were highlighted by the founder as well. They regard the centeredness of decision processes and were explained by the founder as follows:
"I cannot think about everything. In the past, I could do that because the operations were simple and turnover low. Since the organisation became more complex it might be useful to elaborate periodic and synthetic reports about various activities. I needed to get informed about the firm's profitability as well. I needed data on how the business areas are profitable”.

The open office space was introduced by the founder to deal with such kind of problems and with the growth of turnover, which made necessary to manage the whole information flows across the organisation areas. The open office space made the employees' actions more visible to the founder, and made him able to exert a direct control on them. Such a direct control was considered by the daughter as inadequate when the complexity of the organisation increased. She defended her vision arguing:

"At this moment I think is necessary that things are done not in response to some authoritative request but as decisions taken by each manager or employee who is made responsible for the results of his/her tasks".

In line with her vision, Lucia proposed the introduction of a new information system and a cost report tailored for CTA requirements and able to integrate manufacturing and administrative data.

\subsection{Solving organizational and business problems as new possibilities for future actions}

At the beginning of its story, CTA employed some rudimental accounting techniques, which mainly produced handwritten reports without technology support. This was due to the centralisation of the decision making process on the founder. In the past, the founder retained all key information and decision-making authority, and closely supervised employees, giving subordinates little discretionary leadership (Sorenson, 2000; Hunt et al., 1978). He collected all pieces of information about the production, directly controlled the stock account and administrative activities.

After the start-up period and in the middle of nineties, a rudimental information system was introduced in order to electronically manage invoices, overlook the stock and the customers/suppliers accounts, which were still handwritten and entailed some communication problems among the employees. Such problems provoked production delays and misunderstandings in administrative activities. Discussing this argument, the Accountant argued:

"All employees shared only handwritten information about customers and suppliers, it was difficult to rebuild the credit or debt position of a specific customer or supplier. The collection of the data required an over effort in terms of time”.

Thus, the main problem was related to the receipts and payment management, since it was unworkable to classify all receipts and payments on the basis of the date and the typologies (cash, checks, cash order, etc.). The Accountant referred:

"The receipts and payments were out of control because all necessary data were not correctly recorded or shared. Sometimes we were not conscious about missed customer payments, and this reduced our cash flow”.

Other problems were identified by the Production Manager in the mistaken stock accounting due to loading and unloading handwritten documents. This provoked manager's inability to get under control the production process, loss of time and not sufficient information on the current status of the warehouse. The Production Manager argued:

"You could not control effectively the amount of raw materials and accessories stored; it was difficult to manage this situation, arising a lot of inconvenience and loss of time”.

In line with this sense of dissatisfaction, the Customers Manager complained difficulties in providing information on the ready-made products, the ones in the working and those in the planning stages. He explained:

"Response to customer's questions about her order was really difficult, it required a visual inspection and a confirmation from the production office; it again caused a loss of time and a prolonged wait for the customer". 
While the open working space, wanted by the founder, had created a sense of integration among the various managers and employees, no help was offered in the search of a specific customers or suppliers account. Difficulties in the search of all clients' and suppliers' folders risked to undermine the managerial style desired by Lucia. Rather, as she argued:

"In order to collect the pieces of information dispersed among the Customers Manager, the Production Manager and the Accountant, it was the supplier or the customer who had to be invoked. It was the supplier or the customer who had to collect the pieces of information they were looking for, such as information about the state of the client's production order, the state of the payment, the amount of materials in the warehouse, and so on. This required a proper information system which could enable such an integration around a given client or supplier that the system could treat as an object, as an account”.

And she continued:

"Such an information system could allow a regular costs and revenues reporting on each specific group of customers and can give the information on customers' profitability my dad and I are looking for”.

Different meetings were conducted to discuss the problems mentioned above. The management accounting practice proposed was required to play an integrating role among the founder, the new generation, and all the functional managers and employees in order to respond to customers' requests or to manage suppliers' relations more effectively. Integration was the keyword. EasyManage was the software package designed with the help of some engineer in order to develop an intranet platform where business data were to be assembled. Different tools were developed in order to integrate data from various organisational areas. However, during its first use, EasyManage was perceived by its users as unable to provide the information required by specific customers or suppliers. Such a solution seems to be illusionary to both the founder and other managers.

A software company (SC) was contacted for the development of a new software package. CTA signed an agreement with SC in order to define the specifics of the software package and its implementation. However, while the software was still being developed, CTA was provided with a "demo" version of the software. Since its first use, that version appeared to be low flexible and costly. On this matter, an employee, responsible for the new product development, stated:

"The interfaces of the SC system were unbending and the data hard to be modified without the support of the engineers which developed it. This has generated several problems linked to both the low user-friendliness and flexibility of the system, and the additional costs related to the expert advices".

Various problems derived from the need to modify the data uploaded, which, once inserted into the interfaces, required the assistance of SC personnel. Moreover, the cost for assistance was charged per hour, and this was not specified in the agreement. A sense of rigidity was the perceived cost associated to the need for business integration. This new solution was perceived as consistent with the managerial values wanted by Lucia, but its inability to make future actions possible revealed it as a further illusionary practice.

A new solution should overcome such a sense of rigidity and illusion, while pursuing the aim of integrating all the organisational actors around a specific customer or supplier. Such a new solution was found by deeply looking at the EasyManage, the software introduced earlier and still used within the firm. The different EasyManage tools were revised so as to consider client or supplier as the object of data integration. New possibilities were disclosed by revising EasyManage tools. Some integrated application forms were developed which gave all users the possibility to insert new data easily and timely. Consequently, this information system optimised the management of information flows through some shared database that were easily consulted and modified from all positions, offering the possibility to know when they were updated. The new information system was perceived by the founder and his daughter as the organisational practice which made the founder constantly well-informed about the business trends, and made him able to directly apply for reports related to some specific objects (i.e. geographical areas, groups of customers/suppliers, years, etc.).

Through introducing this new practice, Lucia persuaded all CTA’s managers and employees that their assignments could be easier. Different possibilities were disclosed by the new practice. In particular, using bar codes, the new information system could have allowed the loading and unloading of warehouse in real time, the knowledge of the production proceedings, and the recognition of the employees made responsible for each activity. On the other hand, the new information system could have helped to simply classify the different groups of customers/suppliers and to timely monitor the terms of receipts and payments.

At this point, an integration of the main organisational actors was needed. The Production Manager and his staff were required to be responsible for loading and unloading of warehouse, monitoring the production proceedings with 
the support of bar code technology. To do that, at each stage of the manufacturing, operators were required to scan a bar coded label so as to make the manufacturing proceedings visible to all operators and managers. The Accountant was made responsible for the monthly reports of payments, by simply monitoring the respective due dates. The Customer Manager was made responsible for receiving and/or shipping the products, by interacting with customers when necessary.

The development of a cost report that visualises customers' profitability was another new practice to be introduced. This project was developed by Lucia who asked the Customers Manager and the Accountant to define the technical specifics of such report in terms of cost objects and cost configuration. The annual level of the sales was significantly influenced by seasonal effects, being the solar shading systems mostly produced during the spring and the summer time. This required an efficient use of the productive capacity which had to be matched with an effective use of the marketing levers, such as advertising and distribution channels. Lucia gathered such information from the Customers Manager and, talking with the Accountant, learnt that advertising, transportation and even raw materials entailed the most significant costs, the level of which varied among the distribution channels, namely private customers and retailers. Then, Lucia realised that the kind of cost to be managed was not the ones related to productive capacity, namely amortisation, rent, personnel, but the costs of advertising, transportation and materials. She then chose a variable costing as the proper costing method to calculate the contribution margin of private customers and retailers.

\subsection{Practising the construction of successor's leadership. The integrating role of a new information system and cost report}

After the introduction of the new information system and the cost report, each member was able to solve the abovementioned problems. At first, the communication among the organisational areas was improved, considering the possibility of knowing in real-time all manufacturing times, warehouse handlings, dues of customers/suppliers receipts and payments and the contribution margins of specific groups of customers.

The communication among the functional areas was improved through the mediation of EasyManage which, by means of a bar code technology, produced proper reports. An example of report is offered in figure 1, which shows for each client the list of the production jobs still in progress (lista generale ordini aperti per cliente).

Figure 1: EasyManage output on the list of job orders in progress for a specific client

\begin{tabular}{|c|c|c|c|c|c|c|c|c|}
\hline \multicolumn{9}{|c|}{$\begin{array}{l}\text { Lista generale ordni aperti } \\
\text { CLIENTE BETA } 000261\end{array}$} \\
\hline Data & N.ord & Articolo & Descrizione & Q.ta & & & & \\
\hline \multicolumn{9}{|c|}{ CT ACIREALE } \\
\hline \multicolumn{9}{|l|}{ CTA } \\
\hline $02 / 02 / 15$ & $000183 / 010$ & TELI.CONF_60 & Teli Confezionati 60 & $\begin{array}{l}1,00 \mathrm{PZ} \quad \mathrm{L}=397 \\
1,00 \text { prod }\end{array}$ & $\mathrm{H}=230$ & telo $635 / 11$ & Tipo & .. \\
\hline $02 / 02 / 15$ & $000183 / 020$ & TELI.CONF_60 & Teli Confezionati 60 & $\begin{array}{l}1,00 \mathrm{PZ} \quad \mathrm{L}=403 \\
1,00 \text { prod }\end{array}$ & $\mathrm{H}=230$ & telo $=635 / 11$ & Tipo & \\
\hline $08 / 02 / 15$ & $000238 / 010$ & RULLO_SENJA & Tenda a Rullo Acciaio Inox & $1,00 \mathrm{PZ}$ & & & & \\
\hline $08 / 02 / 15$ & $000238 / 020$ & RULLO_SENJA & Tenda a Rullo Acciaio Inox & $1,00 \mathrm{PZ}$ & & & & \\
\hline $08 / 02 / 15$ & $000238 / 030$ & RULLO_AD.100 & Tenda Rullo Standart a Catena & $1,00 \mathrm{PZ}$ & & & & \\
\hline
\end{tabular}

The report visualised in figure 1 makes it possible a control of the manufacturing schedules and warehouse. Indeed, referring to Client Beta, it shows the date of the order and the related number (columns 1 and 2), the item (articolo) and its description (columns 3 and 4) and the quantity already produced (Q.ta, last column). The value of the quantity visualised in the last column is continually updated by means of the bar code labels scanned by operators from the manufacturing stations.

Another report is produced for payment and receipts management, namely the payment and receipt schedule (scadenzario pagamenti e incassi). With specific reference to customers management, any organisational actor can visualise the credit positions of CTA by entering the software the date, the type of receipts (cash, checks, cash order, etc). The receipt schedule (scadenzario incassi) is visualised in figure 2.

\section{Figure 2: Receipt schedule}




\begin{tabular}{|c|c|c|c|c|c|c|}
\hline $06 / 02 / 2015$ & & & & Scadenzario incassi & & \\
\hline Scadenza & Doc. & data & rata Cliente & Dare & Avere & Saldo \\
\hline \multirow[t]{2}{*}{$04 / 01 / 2015$} & 1763/1 FT & $05 / 12 / 2014$ & ALFA & 55,80 & 0,00 & 55,80 \\
\hline & & & & Totale al & $04 / 01 / 2015$ & 55,80 \\
\hline \multirow[t]{2}{*}{$09 / 01 / 2015$} & $7 / 1 \mathrm{FT}$ & $09 / 01 / 2015$ & BETA & 183,00 & 0,00 & 183,00 \\
\hline & & & & Totale al & $09 / 01 / 2015$ & 183,00 \\
\hline \multirow[t]{2}{*}{$16 / 01 / 2015$} & $25 / 1 \mathrm{FI}$ & $1601 / 2015$ & GAMMA & 683,20 & 0,00 & 683,20 \\
\hline & & & & Totale al & $16 / 01 / 2015$ & 683,20 \\
\hline \multirow[t]{2}{*}{$19 / 01 / 2015$} & 1583/1 FT & $21 / 10 / 2014$ & DELTA & $1.417,95$ & 0,00 & $1.417,95$ \\
\hline & & & & Totale al & $19 / 01 / 2015$ & $1.417,95$ \\
\hline \multirow[t]{2}{*}{$21 / 01 / 2015$} & $43 / 1$ FT & $21 / 01 / 2015$ & EPSILON & $5.874,30$ & 0,00 & $5.874,30$ \\
\hline & & & & Totale al & $21 / 01 / 2015$ & $5.874,30$ \\
\hline \multirow[t]{2}{*}{$2701 / 2015$} & $1731 / 1 \mathrm{FT}$ & $28 / 11 / 2014$ & DELTA & $1.018,97$ & 0,00 & $1.018,97$ \\
\hline & & & & Totale al & $27 / 01 / 2015$ & $1.018,97$ \\
\hline \multirow[t]{2}{*}{$29 / 01 / 2015$} & $70 / 1 \mathrm{FT}$ & $29 / 01 / 2015$ & ZETA & 964,00 & 0,00 & 964,00 \\
\hline & & & & Totale al & $29 / 01 / 2015$ & 964,00 \\
\hline $31 / 01 / 2015$ & 1845/1 FT & $23 / 12 / 2014$ & ETA & 244,00 & 0,00 & 244,00 \\
\hline $31 / 01 / 2015$ & $1747 / 1 \mathrm{FT}$ & $03 / 12 / 2014$ & THETA & $11.820,98$ & 0,00 & $11.820,98$ \\
\hline $31 / 01 / 2015$ & $1834 / 1$ FT & $20 / 122014$ & THETA & $2.084,78$ & 0,00 & $2.084,78$ \\
\hline $31 / 01 / 2015$ & $1792 / 1 \mathrm{FT}$ & $15 / 12 / 2014$ & SIGMA & 135,09 & 0,00 & 135,09 \\
\hline $31 / 01 / 2015$ & $1842 / 1 \mathrm{FT}$ & $23 / 12 / 2014$ & SIGMA & 110,69 & 0,00 & 110,69 \\
\hline $31 / 01 / 2015$ & $1648 / 1 \mathrm{FT}$ & $10 / 11 / 2014$ & ALFA & 94,83 & 55,80 & 39,03 \\
\hline $31 / 01 / 2015$ & $1665 / 1 \mathrm{FT}$ & $13 / 11 / 2014$ & ALFA & 39,17 & 0,00 & 39,17 \\
\hline \multirow[t]{3}{*}{$31 / 01 / 2015$} & $1820 / 1 \mathrm{FT}$ & $19 / 12 / 2014$ & ALFA & $1.543,88$ & 0,00 & $1.543,88$ \\
\hline & & & & Totale al & $31 / 01 / 2015$ & $16.017,62$ \\
\hline & & & & & & $26.214,84$ \\
\hline
\end{tabular}

The report visualised in figure 2 makes it possible a control of the credit positions of CTA. Indeed, it shows the date of the credit, the related document and the issued date, the receipts number, the client, (columns 1, 2, 3, 4 and 5) and its numeric description (columns 6, 7 and 8).

A variable cost report satisfied the founder's and his daughter's need to visualise how firm's profitability was distributed among specific groups of customers. Such a report showed the contribution margin of private customers and retailers, as reproduced in figure 3. 
Figure 3: Simulation of CTA's income statement (the values reported are not the true values)

\begin{tabular}{|c|c|c|c|}
\hline \multicolumn{4}{|c|}{2010 Income statement (values in euro) } \\
\hline & \multicolumn{2}{|c|}{ Customers } & \multirow[t]{2}{*}{ CTA } \\
\hline & $\begin{array}{l}\text { Private } \\
\text { customers }\end{array}$ & Retailers & \\
\hline Revenues & 565.852 & 1.700 .479 & $\begin{array}{lr} & 2.266 .33 \\
1 & \end{array}$ \\
\hline Variable costs & 380.967 & 1.114 .158 & $\begin{array}{ll} & 1.525 .12 \\
5 & \end{array}$ \\
\hline $\begin{array}{l}\text { Contribution } \\
\text { margin }\end{array}$ & 184.885 & 556.321 & 741.206 \\
\hline Fix costs & & & 449.652 \\
\hline \multicolumn{3}{|c|}{ Operating income } & 291.554 \\
\hline
\end{tabular}

A cost report similar to the one showed in figure 3 was quarterly produced in order to visualise the profitability trend as a consequence of the seasonal demand which characterises the firm's products. It allows the family members to communicate about the profitability trend and its distribution among the specific groups of customers considered as the most relevant for strategic purposes. The information deriving from this report, drew the founder and his daughter' attention to the improvement of private customers' profitability. A new showroom was opened in the city centre in order to increase the product's visibility to the customers and to dedicate a specific space where the professionals can design product solutions for specific customer's needs.

The reports shown in figures 1, 2 and 3 represent the new communication practices used by the various actors (the founder, the Customers Manager, the Production Manager and the Accountant) to communicate in a managerial style about the future action to take on specific groups of customers, the private customers and retailers. The new information system and cost report constituted the language introduced by the future successor, Lucia, which allow all the actors to act in the future in line with a managerial vision. In this sense, the new information system and cost report can be considered as the new practices that help the future successor in the construction of her leadership.

In this respect, some problems were still present about receipts management. Some lack of communication occurred between the employee who monitored credit positions through EasyManage's interfaces and the Customers Manager. Indeed, in the case of failure to pay by some customer, the administrative was in charge of informing the Customer Manager for the payment solicit in order to avoid bad debts.

Currently, EasyManage and the reports it produces are still in use in CTA. As reported by Lucia:

"Nowadays nobody in CTA can work without EasyManage and its reports. During its introduction and its subsequent reengineering, I had the chance to talk with several operators and employees who told me the main problems they had to face in their work. Sometimes, in case of failure to pay by some customer, I get in touch with the customer and try to kindly find the right solution with him. The Accountant and the Customer Manager appreciate my kindliness. During the last expo in Germany, I knew several new retailers who were interested in our products. I translated what I told them to my dad, who has admitted I've learnt a lot. Actually, right now I fill to be respected by managers, employees, and even customers, for what I know and what I can do, and not for being the daughter of the founder".

All the organisation's members involved acknowledged Lucia's capabilities and her professional contribution to the implementation of the new information system and cost report, as the Accountant argued:

"All the people who worked in CTA had known Lucia since she was a child... she used to do a work experiences during the summer season, thus all managers and employees felt a natural affection to her. When she started constantly working at CTA and brought new ideas into the organisation which improved our daily working, we began appreciating her professional capabilities... she started to actively take part to the CTA!" 


\section{Discussion and concluding remarks}

The previous section told a story about how a new information system and cost report supported the construction of the junior generation's leadership profile. The field evidence highlights the difficulties of the founder in dealing with the increased complexity of his business and the related need to be supported by someone else in the decision making. The awareness of the succession as a future fact that cannot be avoided forced the founder to prompt his oldest daughter to take part in the business. Thus, preparing succession constitutes the starting point which represents the "fact" to be integrated with "values" and "possibilities" through communication practices. Different values emerged from the founder's and his daughter's views. While the former was inclined to increase the visibility of the tasks in order to exert a direct control over his managers and employees, his daughter disapproved this authoritative style. She was oriented toward a managerial style, based on responsibilities and performance information. In other words, two possibilities were disclosed to increase transparency: the open office space, promoted by the founder, and the new information system and cost report, to be introduced by the daughter. The daughter's vision was the prevailing value which motivated the introduction of the later practice. The introduction of the new system and reporting faced several difficulties related to the rigidity of the software tools. Indeed, the different attempts put in place some illusionary solutions. While the first version of EasyManage was perceived as unable to provide the information required by specific customers and suppliers, the other SC software revealed some rigidity in managing the data uploaded. New possibilities were disclosed later on by revising EsayManage tools. The new solution made able the users to insert data easily and timely, in line with the need to make the founder constantly well informed. When put into practice, this later solution constituted the language which allowed the founder, his daughter and CTA managers and employees to integrate what is perceived as possible with what can be considered a real fact under the shared values of a managerial view. The new information system, indeed, help functional managers and employees to know in real time all manufacturing times, warehouse handlings and the contribution margins of specific groups of customers, such as private customers and retailers. "(P)ossibilities create room for choice, but they only function if there is a reason to choose and prefer one possibility to the other i.e. if the actor has values and the values lie within the range of one’s possibilities” (Nørreklit et al., 2010, p.738). A real action, followed from the new possibilities just mentioned, was the opening of a new showroom aimed at increasing the product visibility to the private customers.

It is in disclosing new possibilities for the future and in translating such possibilities into real actions that the new information system and cost report increased the credibility and the trustworthiness of the founder's daughter. The latter was involved in solving the various problems which managers and employees faced, for instance, in managing the customer payments. In doing so, the organisational members recognised the capabilities and the skills of the founder's daughter. More specifically, the performance information system and cost report increased the communication among functional areas and allowed them to act in the future in line with the new generation's managerial vision. "Without communication, only individual reality exists ... Communication is therefore necessary for individual reality to become social. Integration takes place in a social setting and communication is establishing the inter-subjective reality. Communication enables people to cooperate and management to access the subjective worlds of the values and reasoning of employees. Communication allows the objectification of facts, values and reasoning” (Nørreklit et al., 2010, p.745).The new ideas brought into the family firm by the founder's daughter improved the daily working, the communication among functional managers, employees and the founder, helping in the construction of her leadership.

To sum up, the field evidence highlights that the construction of the new generation leadership can be partially unintentional as it may emerge as unintended consequence of the introduction of new information system and cost report, which was well managed by the future successor. Moreover, the field evidence shows how the construction of the new generation leadership is a process that integrates the four dimensions of reality, but it is highlighted that such a process starts from a fact, instead from values, namely the succession in the firm.

Future lines of research may relate to several issues still unexplored in the family business field. A point to be investigated can relate to how management accounting tools can facilitate communication and knowledge integration among family and non-family members, or even across generations. Another point can relate to further stages of the succession process, successive to succession preparation, where management accounting tools may play some critical roles. That of family business looks as a promising and challenging field where management accounting researchers are called to actively contribute. 


\section{References}

Auerbach, C., \& Silverstein, L. 2003. Qualitative Data: An Introduction to Coding and Analysis. New York, NY:University Press.

Barach, J. A., \& Gantisky, J. B. 1995. Successful succession in family business. Family Business Review, 8, 131-155.

Birley, S. 1986. Succession in the family firm: The inheritor's view. Journal of Small Business Management, 24(3), 36-43.

Boje, D. M. 2001. Narrative methods for organizational and communication research. London: Sage.

Bracci, E., \& Maran, L. 2012. The role and use of management accouting systems (MAS) in family firms: a case study. Piccola Impresa/Small Businees, 3, 129-153.

Busco, C., Riccaboni, A., \& Scapens, R.W. 2006. Trust for accounting and accounting for trust. Management Accounting Research, 17, 11-41.

Cabrera-Suàrez, K., De Saa-Pèrez, P., \& Garcìa-Almeida, D. 2001. The succession process from a resource-and knowledge-based view of the family firm. Family Business Review, 14, 37-46.

Cadieux, L. 2007. Succession in small and medium-sized family businesses: Toward a typology of predecessor roles during and after instatement of the successor. Family Business Review, 20, 95-109.

Cater, J.J., III., \& Justis, R.T. 2009. The development of successors from followers to leaders in small family firms: An exploratory study. Family Business Review, 22, 109-124.

Chlosta, S., Patzelt, H., Klein, S., \& Dormann, C. 2012. Parental role models and the decision to become selfemployed: The moderating effect of personality. Small Business Economics, 38, 121-138.

Collinson, D. L. 2006. Rethinking followership: A post-structuralist analysis of follower identities. Leadership Quarterly, 17, 179-189.

Czarniawska, B. 1997. Narrating the organization: Dramas of institutional identity. Chicago: Chicago University Press.

De Massis, A.D., Chua, J.H., \& Chrisman, J.J. 2008. Factors preventing intra-family succession. Family Business Review, 21, 183-199.

DeRue, D. S., \& Ashford, S. J. 2010. Who will lead and who will follow? A social process of leadership identity construction in organizations. Academy of Management Review, 35, 627-647.

Dyck ,B., Mauws F., Starke, A., \& Mischke, G.A. (2002). Passing the baton. The importance of sequence, timing, technique and communication in executive succession. Journal of Business Venturing,17, 143-162.

Dyer, W.G., 1986. Cultural change in family firms: Anticipating and managing business and family transitions. San Francisco: Jossey-Bass.

Fairhurst, G. 2001. Dualisms in leadership research. In F. M. Jablin \& L. L. Putnam (Eds.), The New Handbook of Organizational Communication (pp. 379-439). Newbury Park, CA: Sage.

Fairhurst, G. T. 2009. Considering context in discursive leadership research. Human Relations, 62, 1607-1633.

Fairhurst, G.T., Grant, D. 2010. The Social Construction of Leadership: A Sailing Guide. Management Communication Quarterly, 24(2) 171-210.

Fox, M., Nilakant, V., \& Hamilton, R. T. 1996. Managing succession in family-owned businesses. International Small Business Journal, 15(1), 15-25.

Giovannoni, E., \& Maraghini, M.P. 2013. The challenger of integrated performance measurement systems. Integrating mechanisms for integrated measures. Accounting, Auditing \& Accountability Journal, 26, 6, 978-1008.

Giovannoni, E., Maraghini, M.P., \& Riccaboni, A. 2011. Transmitting Knowledge Across Generations: The Role of Management Accounting Practices. Family Business Review, 24, 2, 126-15.

Grint, K. 2005. Problems, problems, problems: The social construction of “leadership.” Human Relations, 58, 14671494.

Handler, W.C. 1990. Succession in family firms: A mutual role adjustment between entrepreneur and next generation family members. Entrepreneurship Theory \& Practice, 15(1), 37-51.

Hunt, J.G., Osborn, R.N., \& Schuler, R.S. 1978. Relations of discretionary and nondiscretionary leadership to performance and satisfaction in a complex organization. Human Relations, 31, 507-523.

Jakobsen, M., Johansson, I.L., \& Nørreklit, H. 2011. An Actor's Approach to Management. Conceptual Framework and Company Practices. Copenhagen: DJØF Publishing.

Kajüter, P., Kulmala, H.I. 2005. Open-book accounting in networks: Potential achievements and reasons for failures. Management Accounting Research, 16, 2, 179-204.

Kelly, L.M., Athanassiou, N., \& Crittenden, W.F. 2000. Founder centrality and strategic behavior in family-owned firm. Entrepreneurship Theory and Practice, 25(2), 27-42.

Lansberg, I. 1988. The succession conspiracy. Family Business Review, 1(2), 119-143.

Lansberg, I. 1999. Succeeding generations: Realizing the dream of families in business. Boston: Harvard Business School Press. 
Lansberg, I. 2007. The tests of a prince. Harvard Business Review, 85(9), 92-101.

Le Breton-Miller, I., Miller, D., \& Steier, L.P. 2004. Toward and integrative model of effective FOB succession. Entrepreneurship Theory and Practice, 28, 305-328.

Malone, S.C. 1989. Selected correlates of business continuity planning in the family business. Family Business Review, 2(4), Winter, 341-353.

Mazzola, P., Marchisio, G., \& Astrachan, J. 2008. Strategic planning in family business: A powerful developmental tool for the next generation. Family Business Review, 21, 239-258.

Meindl, J.R. 1995. The romance of leadership as a follower-centric theory: A social constructionist approach. Leadership Quarterly, 6, 329-341.

Miller, D., Steier, L., \& Le Breton-Miller, I. 2003. Lost in time: Intergenerational succession, change and failure in family. Journal of Business Venturing, 18, 513-53.

Mitchell, F., Nielsen, L.B., Nørreklit, A., \& Nørreklit, L. 2013. Scoring strategic performance: a pragmatic constructivist approach to strategic performance measurement. Journal of Management and Governance, 17(1): 5-34.

Nor-Aziah A., \& Scapens R.W., 2007. Corporatisation and Accounting Change: The Role of Accounting and Accountants in a Malaysian Public Utility. Management Accounting Research, 18, 209-247.

Nørreklit, H., Nørreklit, L., \& Mitchell, F. 2007. Theoretical conditions for validity in accounting performance measurement, in Neely, A. (Ed.), Business Performance Measurement - Frameworks and Methodologies, Cambridge University Press, Cambridge, pp. 179-217.

Nørreklit, H., Nørreklit, L. \& Mitchell, F. 2010. Towards a paradigmatic foundation for accounting practice, Accounting, Auditing \& Accountability Journal, 23, 6, 733-758.

Nørreklit, L., Nørreklit, H. \& Israelsen, P. 2006. Validity of management control topoi - towards a constructivist pragmatism. Management Accounting Research, 17, 1, 42-71.

Salvato, C., \& Corbetta, G. 2013. Transitional Leadership of Advisors as a Facilitator of Successors’ Leadership Construction. Family Business Review, 26, 3, 235-255.

Salvato, C., \& Moores, K. 2010. Research on accounting in family firms: Past accomplishments and future challenges. Family Business Review, 23, 193-215.

Sardeshmukh, S.R., \& Corbett, A.C. 2011. The duality of internal and external development of successors: Opportunity recognition in family firms. Family Business Review, 24, 111-125.

Scapens, R.W. 2004, Doing case study research”. In The real life guide to accounting research, Christopher, E. and Lee, B. (Ed). Elsevier Lrd, Oxford, UK.

Seal, W. 2012. Some proposals for impactful management control research. Qualitative Research in Accounting \& Management, 9(3): 228-244.

Shachar, R., \& Eckstein, Z. (2007). Correcting for bias in retrospective data. Journal of Applied Econometrics, 22, 657 -675 .

Sharma, P., Chrisman, J.J., Pablo, A.L., \& Chua, J.H. 2001. Determinants of initial satisfaction with the succession process in family firms: A conceptual model. Entrepreneurship Theory \& Practice, 25(3), 17-35.

Smircich, L., \& Morgan, G. 1982. Leadership: The management of meaning. Journal of Applied Behavioral Science, 18, 257-273.

Songini, L., Gnan, L., \& Malmi, T. 2013. The role and impact of accounting in family business. Journal of Family Business Strategy, 4, 2, 71- 83.

Sorenson, R.L. 2000. The contribution of leadership style and practices to family and business success. Family Business Review, 13, 183-200.

Stewart, A., Hitt, M.A. 2012. Why can’t a family business be more like a nonfamily business? Modes of professionalization in family firms. Family Business Review, 25, 58-86.

Uhl-Bien, M. 2006. Relational leadership theory: Exploring the social processes of leadership and organizing. The Leadership Quarterly, 17, 654-676.

Venter, E., Boshoff, C., \& Maas, G. (2005). The influence of successor-related factors on the succession process in small and medium-sized family businesses. Family Business Review, 18, 283-303.

Vine, B., Holmes, J., Marra, M., Pfeifer, D., \& Jackson, B. 2008. Exploring coleadership talk through interactional sociolinguistics. Leadership, 4, 339-360.

Walsham, G. 2006. Doing interpretative research. European Journal of Information Systems, 5, 320-330.

Ward, J.L. 1987. Keeping the Family Business Healthy. Jossey-Bass: San Francisco, CA.

Yin, R. 2003. Case Study Research: Design and methods. London: Sage Publications. 